\title{
Recruiting for the profession
}

\author{
By Jonathan D. Lauer \\ Head of Public Services \\ Wheaton College
}

\section{How one library publicizes careers in information science.}

$\mathbf{O}$ to which one feels compelled to encourage bright, young adults to enter one's chosen field. We in librarianship, in order to improve the future quality of our profession, ought to give more consideration to the question of recruitment. In his Passion for Books Lawrence Clark Powell reprints a memorandum he once wrote his staff:

Staff members should remember that our profession does not automatically perpetuate itself. A good measure of a library - and of each department in that library - is the number of students or clericals it has recruited for Librarianship. Each of you should ask yourself the question, What have I done and what am I doing toward peopling my profession?... Every student who works for us is a potential librarian.

The best recruits are those who are inspired by the librarians for whom they work to see in Librarianship a dynamic service profession. "Love of books" is not enough. Offer no refuge to the escapist; discourage the dilettante; pity the spiritual misfit, but close the door to the maladjusted. Librarianship holds no magic therapy. Its successful practice calls for normal (not average) men and women. Good health, good nature, good senselook for these qualities.

We do not wish to recruit students all of one type. Keep the varied aspects of our work in mind when you are sizing up a prospect. Neither pure extravert nor introvert makes the best librarian; most of us are hybrids, and properly so.'

Some 25 years later, enter John Naisbitt. If Naisbitt

\footnotetext{
${ }^{1}$ Lawrence Clark Powell, A Passion for Books (New York: World Publishing, 1958), pp. 125-26.
}

is correct in Megatrends, and it seems hard to deny that he is, ours is an expanding field, one in which new and varied opportunities are becoming available. Whether "Information Professional" will become the preferred term to describe practitioners of the gathering, controlling, and dissemination of information is an open issue. However, the fact that graduates of our professional schools are increasingly entering positions in non-traditional library settings is readily apparent. The moment seems ripe for the seizing.

Our library faculty was recently involved in a venture aimed at interesting capable students in thinking about careers dealing with information. Our relatively modest beginning took the form of a one evening seminar entitled, "Career Opportunities as an Information Professional." What follows is a report of the planning and presentation of that seminar.

Earlier this year we in public services were charged with the responsibility of establishing an annual library-sponsored, student-oriented discussion group, workshop, or seminar. This activity was not conceived as relating to the utilization of library resources, but was rather intended to provide contact between professional librarians and students, to dispel stereotypes and change perceptions. In the Fall semester we initiated discussion with the campus career development office. It was agreed that before further work be undertaken, a steering committee should be formed composed of representatives from career development, the student body, the teaching faculty, and the library faculty. This committee proved most helpful, as 
several perspectives were necessary to make optimal decisions regarding numerous planning issues.

\section{Calendar}

College and university campuses are classic cases of overkill when it comes to opportunities for extracurricular educational and entertainment activities. We sought to schedule a time when there were no significant calendar conflicts (major athletic events, dramatic performances, etc.). Further, we chose a date that was three weeks into the new academic term, a time when students were back into their routines, but before the toll of the heaviest pressures. Third, we held the seminar on a Wednesday evening, a time when students enjoy a short distraction.

\section{Content of the seminar}

From the outset it was our desire to strike a balance between an academic and a practical approach to the seminar. Originally, we had planned a twenty minute lecture on the history of information gathering to be followed by presentations on the education of the information professional, employment opportunities, salaries, and career paths. The student representative on the steering committee suggested shortening the background and emphasizing the present opportunities in the field. This proved a fruitful admonition. It was also agreed that outside speakers representing corporate libraries would be a drawing card. So the final phase of the seminar was given over to three speakers, two from Chicago libraries (we paid travel expenses for each and a small honorarium), and one from our library, charged with the task of talking about their work, their job satisfaction, and how their education had prepared them for their daily responsibilities.

\section{Publicity}

Planning publicity for a new venture can be a precarious business indeed, especially when one has booked a room with seating capacity of only 32 with no way of knowing what kind of interest our seminar would generate. (Recent history at the career development office showed about four graduates yearly expressing an interest in library science.) Fortunately, career development did have some experience in planning similar undertakings, but their track record was not particularly encouraging. Some seminars drew as few as four attendees; 20 was considered a good turnout. To avoid an embarrassingly low attendance we decided to err on the side of overkill as far as publicity was concerned. Career development agreed to include a blurb in their general campus mailings, but that was only a token beginning. A student graphic artist was hired to design a broadside, which was distributed to the entire campus community of 3200 individuals. Posters were placed in areas of heavy student traffic. Both the broadside and the posters played on the Megatrends tie-in, a device apparently quite effective. The student on the steering committee wrote an article for the campus newspaper, which appeared in the issue just prior to the seminar. In addition, the campus news coordinator sent a news release to the local papers. Various faculty agreed to announce the meeting in class.

\section{"Love of books" is not enough.}

Gentle reminders in casual conversation spread the particulars of the event by word of mouth.

The upshot of all this is that the night of the seminar the room was filled to capacity, including 12 members of an LTA class and their instructor from a local community college, who were attending the program in lieu of class. Coffee and donuts were served at intermission, though it is difficult to know how much attention the serving of refreshments generated. The publicity for the seminar is itself a case study in the dissemination of information.

\section{Seminar format}

The seminar was presented in a lecture format. An outline of the session's content was distributed to each participant. For the coverage of salaries and placements, appropriate handouts were distributed. There were numerous library school catalogs and relevant pieces of literature available for perusal. A bibliography of books relevant to the seminar content, produced in part with the assistance of an online literature search, was made available. Though response was good throughout the session, the highlight of the seminar was the final 45 minutes in which the invited guests talked about their work. Each of the three speakers had very different perspectives and interests, while at the same time conveying a realistic picture of the workaday world of the information professional. The speakers were received enthusiastically and established excellent rapport with their audience as evidenced by the post-seminar informal interaction.

\section{Follow-up}

Since the seminar, several students have filtered into our offices to discuss further the opportunities available in our profession. One or two have even taken the time to listen to the audio-tape of the seminar. Others have requested copies of the handouts. In sum, the seminar has helped communicate our interest in telling students about the work we do and what is involved in becoming a professional 
librarian. Further, our relationship with career development has been enhanced greatly through our mutual planning and interaction.

\section{Concluding remarks}

Ought we to recruit for our profession? We say yes, and with an enthusiastic recommendation that you try something similar to our initial attempt! (You will need a minimum budget of about \$300). The planning involved in a such venture is considerable, but the visibility and reward that accrue in the process are gratifying. In higher education we are in the business of opening the minds of our students. That "library and information science" exists will be revelatory to many. That it is a true academic discipline will be shocking to most. But the study and practice of librarianship in its growing dimensions will be pleasantly surprising to at least a few.

The author wishes to thank his colleague, Daniel J. Bowell, for his criticism and editorial assistance.

\section{ACRL officers for 1984-85}

\section{The official ACRL election results.}

$\mathrm{S}_{\mathrm{H}}$ J J RoGERS, university librarian at George Washington University (Washington, DC 20052), is the forty-seventh president of the Association of College and Research Libraries. During her one-year term of office, she will preside over the ACRL Board of Directors and the ACRL Executive Committee. She will chair the ACRL Conference Program Planning Committee for the 1985 ALA Annual Conference in Chicago and will plan ACRL's major program at the conference.

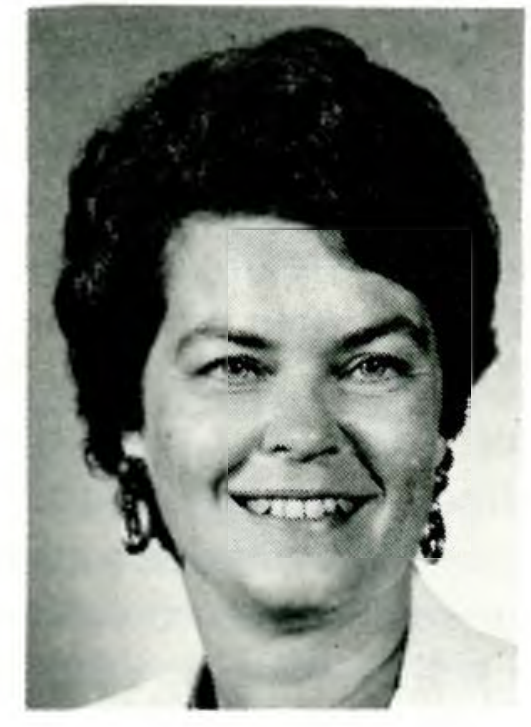

Sharon J. Rogers
As president of the di-

vision, Rogers will represent ACRL on the ALA Chicago Conference Program Committee. She will also represent ACRL and ALA in their relations with other organizations. Rogers has contributed to ACRL as a member of the ACRL Board of Directors, as chair of the Task Force on Academic Libraries and Higher Education, as chair of the Advisory Committee for the Bibliographic Instruction
Liaison Project, and as chair of the Bibliographic Instruction Section (1980-1981). Last year she served as chair of the Legislation Subcommittee of the ALA Status of Women in Librarianship Committee, and as a member of the OHIONET OnLine Reference Council.

Sharon Anne Hogan, director of the Troy Middleton Library, Louisiana State University (Baton Rouge, LA 70803), has been elected vicepresident/presidentelect of the Association of College and Research Libraries. The 1984 election results showed 1,240 votes for Hogan and 1,024 for Janice $T$. Koyama, head of Moffitt Undergraduate Library at the University of California, Berkeley.

As vice-president/ president-elect of ACRL, Hogan will serve on the ACRL Board of

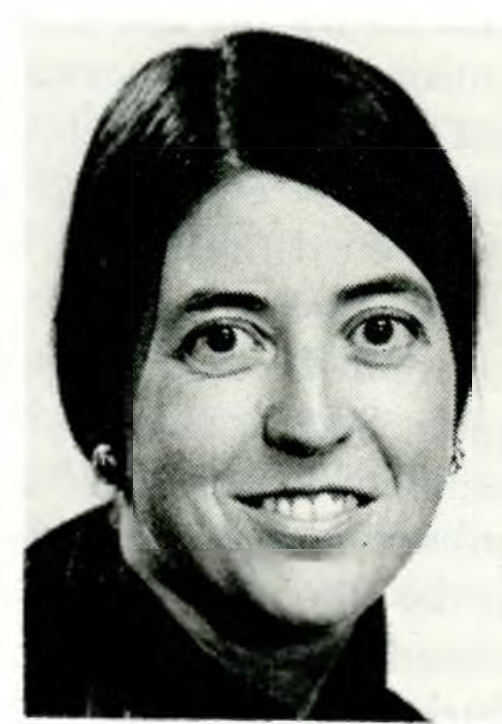

Sharon Hogan Directors and the ACRL

Executive Committee. She will chair the ACRL 